\title{
Occurrence, properties and pollution potential of environmental minerals in acid mine drainage
}

\author{
T. MARia VALente ${ }^{(1)} ;$ C. Leal Gomes ${ }^{(1)}$ \\ ${ }^{(1)}$ Centro de Investigação Geológica, Ordenamento e Valorização de Recursos (CIG-R) - \\ Universidade do Minho, Campus de Gualtar, 4710-057 Braga, Portugal
}

T. Maria Valente

EMail: teresav@dct.uminho.pt

\begin{abstract}
This paper describes the occurrences, the mineralogical assemblages and the environmental relevance of the AMD-precipitates from the abandoned mine of Valdarcas, Northern Portugal. At this mining site, these precipitates are particularly related with the chemical speciation of iron, which is in according to the abundance of mine wastes enriched in pyrrhotite and pyrite. The more relevant supergene mineralogical assemblages include the following environmental minerals: soluble metal-salts, mainly sulphates, revealing seasonal behaviour, iron-hydroxysulphates and iron-oxyhydroxides, both forming ochre precipitates of poorly and well-crystalline minerals.

Pollution potential of the most highly water soluble salts was analysed in order to evaluate the environmental effect of their dissolution by rainfall. Laboratory experiments, carried out with iron and aluminium sulphates, demonstrated the facility to release metals, sulphate and acidity upon dissolution. Regarding the ochre precipitates, composed by several less soluble iron (III)-minerals, the spatial distribution on the nearby aqueous system as well as the proportion of Jarosite, Schwertmannite and Goethite in the mixtures gave information about the halo's contamination promoted by the AMD emerging from the waste-dumps.
\end{abstract}

Keywords: Acid mine drainage, environmental minerals, sulphate efflorescences, ochre precipitates, Valdarcas - Portugal. 


\section{Introduction}

Acid mine drainage (AMD) that emerges from sulphide-rich waste-dumps, exposed to weathering processes, is an important focus of environmental impact world widely. There are numerous examples of globally affected mining regions as AMD promotes chemical, physical, biological and ecological interactive effects on the ecosystems (Gray, 1998; Elbaz-Poulichet et al., 2001; Sainz et al., 2004; Valente and Leal Gomes, 2007).

Associated complex chain of biotic and abiotic reactions that involve the oxidative dissolution of sulphides, generating AMD, has been the subject of extensive literature (McKibben and Barnes, 1986; Bhatti et al., 1993; Ritchie, 1994; Evangelou and Zhang, 1995; Nordstrom and Southam, 1997; Keith and Vaughan, 2000). Eq. (1) to (3) represent the reactions concerning some of the most common sulphide minerals.

Pyrite and Marcasite: $\mathrm{FeS}_{2(\mathrm{~s})}+15 / 4 \mathrm{O}_{2(\mathrm{~g})}+7 / 2 \mathrm{H}_{2} \mathrm{O}_{(\mathrm{l})} \rightarrow \mathrm{Fe}(\mathrm{OH})_{3(\mathrm{~s})}+2 \mathrm{SO}_{4}^{2-}{ }_{(\mathrm{aq})}+4 \mathrm{H}_{(\mathrm{aq})}^{+}$

Pyrrhotite: $\mathrm{Fe}_{1-\mathrm{x}} \mathrm{S}_{(\mathrm{s})}+(9-3 \mathrm{x}) / 4 \mathrm{O}_{2(\mathrm{~g})}+(5-\mathrm{x}) / 2 \mathrm{H}_{2} \mathrm{O}_{(\mathrm{l})} \rightarrow(1-\mathrm{x}) \mathrm{Fe}(\mathrm{OH})_{3(\mathrm{~s})}+\mathrm{SO}_{4}{ }_{(\mathrm{aq})}^{2-}+2 \mathrm{H}^{+}{ }_{(\mathrm{aq})}$

Chalcopyrite: $\mathrm{CuFeS}_{2(\mathrm{~s})}+15 / 4 \mathrm{O}_{2(\mathrm{~g})}+7 / 2 \mathrm{H}_{2} \mathrm{O}_{(\mathrm{l})} \rightarrow \mathrm{Fe}(\mathrm{OH})_{3(\mathrm{~s})}+\mathrm{SO}_{4}{ }^{2-}{ }_{(\mathrm{aq})}+\mathrm{Cu}^{2+}{ }_{(\mathrm{aq})}+4 \mathrm{H}^{+}{ }_{(\mathrm{aq})}$

These primordial reactions are often used to demonstrate, in a simplified way, the two main results of mineral-water interactions involving sulphides: the generation of an highly contaminant effluent (related with the production of acidity, sulphate and metallic dissolution) and the development of supergene or newly formed iron-rich minerals (generically represented by the ferric-hydroxide $\left.\mathrm{Fe}(\mathrm{OH})_{3(\mathrm{~s})}\right)$. These supergene minerals are generically called AMDprecipitates since they appear in the dependence of AMD upon evaporation, oxidation, hydrolysis and neutralization.

The geochemical and mineralogical evolution of the sulphide-rich wastes can be expressed by mild modifications of the primary paragenesis or by profound transformations, which end in new mineralogical structures, some of them with complex compositional and textural patterns, 
such as iron-rich hardpans (Courtin-Nomade et al., 2003; Gilbert et al., 2003; Lottermoser and Ashley, 2006; Pérez-López et al., 2007). The AMD-precipitates attest the principal evolutionary steps, and, consequently, they reflect stages of momentary stability.

The iron-oxyhydroxides, which are the final terms of such supergene evolution, are welldocumented AMD-precipitates (Schwertmann et al., 1987; Bigham et al., 1994; Singh et al., 1999; Bigham and Nordstrom 2000; Kawano and Tomita, 2001; Dold, 2003; Murad and Rojík, 2003; Valente and Leal Gomes, 2005). They occur as ochre mixtures, conferring strong visual impact to the watercourses, which may decide their protagonist role in mining environments. However, the evolution of the sulphide-rich wastes is marked by other newly formed minerals that may involve intermediary terms, such as clay minerals, hydrated salts, metallic oxides, arsenates, carbonates, phosphates and native elements. Often, these minerals come in concert with supergene materials that didn't realized crystalline structure. From these groups, hydrated soluble salts, mainly metal-sulphate minerals, have been deserved careful attention. Although metastable, and therefore ephemeral, they have strong influence on the superficial environments (Dold and Fontboté, 2001; Hammarstrom et al., 2005; Harris et al., 2003). They also may give valuable information concerning the primary minerals and the composition of the solutions from which they formed as well as about the prevailing equilibrium conditions on waste-dumps.

There are several works that document the role of the soluble sulphates in AMD environments (e.g. Cravotta, 1994; Hudson-Edwards et al., 1999; Nordstrom and Alpers, 1999; Buckby et al. 2003; Sanchéz et al., 2005), some of them testifying the discovery of new minerals (e.g. Jambor and Boyle, 1962). A detailed review that emphasises the relevance of metal-sulphates, from a variety of perspectives including paragenetic relations and climate control, is provided by Alpers et al. (2000).

Supergene materials from sulphide mineral oxidation have great relevance in environmental mineralogy, concerning their role controlling pollutants in contaminated environments (Cotter- 
Howells et al., 2000; Hochella, 2002; Vaughan et al., 2002). Both, metal soluble-sulphates, occurring as efflorescences, and iron (III)-minerals that form ochre precipitates, are keyexamples of environmental minerals in the acceptation given by Valsami-Jones (2000). The firsts are worthy of this mention because they are highly soluble hosts of pollutants; their role in the release of metals and acidity, upon dissolution by rainfall, is well documented (Buckby et al., 2003; Gomes and Favas 2006; Alpers et al., 1994; Frau, 2000). The second group comprises less soluble hosts, which are often poorly crystalline phases with large surface areas. Consequently, they reduce the mobility of toxic elements, including metals and metalloids, which are retained by adsorption and coprecipitation (Smith et al., 1998; Carlson et al., 2002; Hammarstrom et al., 2003; Lottermoser, 2003). The ability to indicate, sometimes in an expeditious way, the prevailing conditions in the contaminated environment, in which they are stable, gives another sense to the specific mention of environmental minerals.

This paper documents the supergene environmental minerals generated in the dependence of the AMD conditions, at Valdarcas mining site (Northern Portugal). It provides an inventory of soluble salts and of less soluble iron-rich minerals identified at the waste-dumps and in the nearby aquatic system. Morphologic and composition aspects as well as paragenetic relations are presented for typical minerals and assemblages.

The environmental relevance of both types of AMD-precipitates is shown in two perspectives: 1) the pollution potential of typical soluble sulphates, which was demonstrated by laboratory dissolution experiments and 2) the ability of ochre precipitates to reveal the AMD conditions and therefore to act as mineralogical indicators of AMD.

\section{Site description}

Valdarcas mine is located in Northern Portugal, in a region where metal mining has large and long tradition (Fig. 1). Wolframite and scheelite were exploited for tungsten in a skarn ore 
deposit, which is rich in sulphides. The most intensive works took place underground, between the fifties and eighties, and have left about $310000 \mathrm{~m}^{3}$ of processing wastes that have resulted mainly from grinding (grain size of about $2 \mathrm{~mm}$ ) and from minor treatment by flotation.

Fig.1. Location of Valdarcas mining site in Northern Portugal and surface map of the waste-dumps.

Table 1 lists the minerals, from the ore deposit, that compose the mine wastes. Besides ore minerals, gangue comprises three main classes that display contrasting geochemical behaviour when exposed to weathering conditions at the waste-dumps. They are by decreasing order of abundance: sulphides (promoting acidity) $>$ silicates (slow consumers of acidity) $>$ carbonates (fast consumers of acidity). The sulphides are mainly represented by massive pyrrhotite and pyrite (about $95 \%$ of the sulphide mass) (Valente, 2004). Therefore, the mine wastes consist primarily of the most reactive and acid producing sulphide phases (Bhatti et al., 1993; Kwong and Lawrence, 1994; Plumlee et al., 1995; Jambor and Blowes, 1998).

Table 1 Most typical minerals from the ore deposit that were also identified at the wastedumps (Valente, 2004).

Mine wastes, carrying these minerals, were accumulated in three major impoundments built without drainage control, which went far towards the strong physical instability. Mechanisms of water erosion, such as sheet, rill and gully erosion, have created impressive marks, like the two deep gullies illustrated in Fig. 1. The topographic irregularities are important because they control the terrain aspect and terrain slope. These, by their turn, allow the development of microclimate conditions that must be considered when studying the occurrences of supergene minerals. 
For decades, AMD has emerged from the waste-dumps exposed to weathering processes. Nowadays, marks of environmental impact still persist on the nearby aqueous system, mainly due to the discharge of acidic effluents in a small stream (Poço Negro creek), and then in the Coura river (Fig. 1 and Fig. 2).

Rainfall is the principal water supply for mineral-water interactions involving the mine wastes at Valdarcas. The region has a temperate climate and is located in the rainiest province of Portugal. Monthly precipitation range from $625 \mathrm{~mm}$ to $1455 \mathrm{~mm}$, values corresponding respectively to the dry semester (from April to September) and to the wet semester (from October to March, with January as the rainiest month). Average annual temperature is $12.5^{\circ} \mathrm{C}$, being January also the coldest month (mean $9.4^{\circ} \mathrm{C}$ ), while in the summer, July and August present the highest temperatures (mean $25.7^{\circ} \mathrm{C}$ ) (www.inag.pt). Measurements at the wastedumps for relative humidity gave maximum in winter $(80$ to $100 \%)$ and minimum $(<20 \%)$ between June and August.

\section{Methods}

Sampling of minerals and water (AMD) took place over about six years of field work (between January 2001 and February 2007), dedicated to construct an extensive and diversified database capable to assist the AMD modelling efforts at this mining site. Several campaigns were carried out, ensuring a minimum of four visits per year in order to represent the climatic seasonality.

\subsection{Mineral sampling and analysis}

For soluble sulphates, sampling fell on the waste-dumps, covering the plain surfaces, the two main gullies illustrated in Fig. 1 and other temporal varying terrain irregularities, in such a way 
to represent different conditions of sun exposure, humidity and topography. Samples were also collected along the Poço Negro creek, whenever their presence was detected.

As far as iron ochre mixtures are concerned, since they are ubiquitous, samples were grabbed from fixed locations at the waste-dumps and at the Poço Negro creek streambed, obeying to the sampling stations represented in Fig. 2.

Fig. 2. Location of the sampling stations, for ochre precipitates and AMD, at the wastedumps and along the main effluent channel (Poço Negro creek).

Samples were stored in closed plastic bags and transported to the laboratory soon after the collection, in order to prevent mineralogical changes.

Mineralogical composition was analysed by x-ray powder diffraction (XRD) with a Philips X'pert Pro-MPD difractometer, using $\mathrm{Cu}-\mathrm{K} \alpha$ radiation. Sample preparation procedures and the appropriated XRD conditions for these kinds of samples, in particular leading with low crystallinity, fine grain size, impurity of the assemblages and high hydration states are described in Valente (2004). Fig. 3 shows the iterative procedure used to refine samples and to achieve mineral identifications. Specifically with respect to the most instable salts, binocular microscopy and XRD were performed immediately after arriving to the laboratory, and the samples were reanalyzed to evaluate aging effects.

Scanning electron microscopy (on carbon or gold coated samples), with a LEICA S360 microscope, combined with an energy dispersive system (SEM-EDS), allowed the study of morphological and compositional aspects. In some cases, it helped in the identification of complex assemblages and of amorphous materials.

Fig. 3. Iterative protocol for mineral identifications in soluble sulphate assemblages. XRD

- Powder x-ray diffraction; SEM - Scanning electron microscopy; SE - Secondary electrons. 


\subsection{Characterization of $A M D$}

AMD was characterized through samples collected at the sampling stations indicated in Fig. 2 (the same stations as for ochre precipitates). This work presents the hydrochemical characteristics of samples collected at two sampling stations representing discriminative environments: at the waste-dump surface (ValdR) and downstream in the Poço Negro creek (V7). The $\mathrm{pH}$ range is also provided for the rest of the stations. At V7 water flow is permanent; at ValdR water is ephemeral and then sampling was dependent on ponded water availability. A complete characterization of the system, including all the sampling stations, is provided in Valente and Leal Gomes (2008).

$\mathrm{pH}$, electric conductivity $(\mathrm{EC})$, redox potential and temperature of the water were measured in the field with a multi-parameter meter (Orion, model 1230). The following Orion probes were used: combined pH/ATC electrode Triode ref. 91-07W, conductivity cell DuraProbe ref. 0133030 and a redox combination electrode ORP ref. 96.78. Before use, electrodes were calibrated and/or tested for accuracy, according to the manufacturer's instructions. Direct measurements of redox potential were converted relative to the hydrogen electrode (EH), using standard voltages from the manufacturer.

After collection, samples were immediately refrigerated, transported in polyethylene bottles kept in the dark and stored at $4^{\circ} \mathrm{C}$ until analysis. Laboratory analyses were performed for fluoride and chloride by ion chromatography (IC) with suppressed conductivity detection (761 Compact IC Metrohm). Sulphate was measured by turbidimetry and total acidity by volumetric determination (Standard methods for water analysis reference 4500E and 2310B, respectively). Inductively coupled plasma-atomic emission spectroscopy (ICP-AES) and atomic absorption spectroscopy (AAS) were used for metals. IC, ICP-AES and AAS analyses were preceded by sample filtration through $0.2 \mu \mathrm{m}$ pore-diameter cellulose ester membrane filters, carried out 
immediately after arriving to the laboratory. For the analysis of metals, filtration was followed by acidification with $\mathrm{HNO}_{3} 65 \%$ suprapur Merck.

\subsection{Laboratory dissolution experiments}

The dissolution of soluble sulphates was simulated in the laboratory, using air-dried materials collected at the waste-dumps. Two typical efflorescences from Valdarcas wastedumps were submitted to dissolution in ultra-pure water: samples carrying hydrated ironsulphates in the assemblage Melanterite $\left(\mathrm{FeSO}_{4} 7 \mathrm{H}_{2} \mathrm{O}\right)+$ Rozenite $\left(\mathrm{FeSO}_{4} 4 \mathrm{H}_{2} \mathrm{O}\right)$ and pure samples of the mixed iron and aluminium-sulphate halotrichite $\left(\mathrm{FeAl}_{2}\left(\mathrm{SO}_{4}\right)_{4} 22 \mathrm{H}_{2} \mathrm{O}\right)$. The experiments were performed by the following protocol:

- Temperature and dissolution conditions: room temperature $\left(20^{\circ} \mathrm{C}\right)$ with constant slow agitation;

- Solution: ultra-pure water from Millipore system, with electric conductivity of $0.1-0.4$ $\mu \mathrm{S} / \mathrm{cm}$ (50 to $100 \mathrm{~mL}$ of solution, depending on the amount of available sample);

- $\quad$ Salt concentrations $-0.4 ; 2.0 ; 20$; and $250 \mathrm{~g} / \mathrm{L}$;

- Duration of experiments - 15 minutes;

- Control parameters: the acid producing potential was determined from $\mathrm{pH}$ continuous measurements; the metals $\mathrm{Mn}, \mathrm{Fe}, \mathrm{Al}, \mathrm{Cu}, \mathrm{Zn}$, the metalloid As, as well as the anions Fluoride, Chloride and Sulphate were analysed in the final solution (using the same methods as for AMD analyses).

\section{Results and discussion}


Table 2 records the supergene materials identified at the waste-dumps and downstream in the main effluent channel (Poço Negro creek). Information about abundance and seasonal persistence is included. These materials define two main modes of occurrence:

- Efflorescences (EFL) - products of evaporative processes composed by soluble metal salts, appearing monomineralic or as mineral assemblages;

- Ochre precipitates (OP) - products of oxidation and neutralization comprising relatively insoluble iron(III)-bearing minerals, often as mixtures, displaying ochre colours.

As secondary precipitation proceeds, salt efflorescences and ochre precipitates may develop encrustation processes. In that case, they lead to thick salt crusts or iron-rich crusts respectively. When well-developed, such encrusting products act like supergene cement for primary and secondary minerals. Some materials, like lepidocrocite, were observed only inside solid crusts (CRUS) while others were detected only as powdered efflorescences (ex: mallardite) or as relatively loosely ochre precipitates (amorphous iron sulphate). Minerals, such as melanterite and gypsum are typically involved in encrustation processes, and, therefore, it is possible to observe the evolutionary process (EFL $\rightarrow$ CRUS).

\section{Table 2 AMD-precipitates identified at Valdarcas.}

The mineral classes can be organized in accordance with abundance, in the following manner:

oxyhydroxides and sulphates $>$ silicates (clay minerals) $>$ carbonates $>$ native element.

Regarding chemical composition there are species of alkali and alkaline earth metals, transition metals and aluminium. Precipitation of calcium occurs mainly as gypsum and calcite. Calcite is rarely individualized in macroscopic samples at the waste-dumps, being detected mainly inside consolidated crusts. It can also be observed, as efflorescences, over course fragments of waste 
rock from mining operations that are exposed around the mining site. Gypsum is very abundant and omnipresent, even in wet conditions.

Concerning iron sulphates, the inventory includes mainly simple hydrated salts with ferrous iron. Rozenite and melanterite are the more common soluble iron minerals, occurring as efflorescences. Trivalent iron was only found in relatively insoluble oxyhydroxides (ex: goethite) and hydroxysulphates (ex: jarosite).

Aluminium forms a variety of soluble sulphates, including alunogen, rostite-khademite and halotrichite. Zinc and manganese have also mineralogical expression, although rare, by means of the heptahydrates gunningite and mallardite, respectively. There are also amorphous materials composed by silica, iron-oxyhydroxides and iron phosphates.

\subsection{Efforescences of soluble sulphates}

Efflorescent mineralogy is formed in dry conditions by precipitation as AMD become more concentrated by evaporation. Efflorescences comprising the soluble sulphates are often complex mixtures, concerning mineralogy and morphology.

\subsubsection{Mineralogy and morphology}

Efflorescences were more often observed in complex miscellaneous assemblages and rarely as single phases. Fig. 4 to Fig. 6 show XRD patterns for some common or representative identified assemblages.

Gypsum is the most abundant mineral that occurs as efflorescences. It is an exception since it grows frequently as monomineralic rosettes or as spherical concretions, often cemented by jarosite (Fig. 7 a, b)). However, at the same time, gypsum was detected in the major saline polymineralic aggregates. 
Fig. 4. XRD pattern from a complex assemblage including the abundant iron sulphates (rozenite and melanterite) and the more rare zinc (gunningite) and alkaline earth metals (starkeyite and gypsum) sulphates. Pattern peaks from ICDD.

Fig. 5. XRD patterns of efflorescences carrying several Al-sulphates. Pattern peaks from ICDD

Fig. 6. XRD pattern from a complex assemblage including iron (melanterite and siderotil), manganese (mallardite) and aluminium sulphates (tamarugite). Pattern peaks from ICDD.

Rozenite is also a very abundant mineral at Valdarcas (Fig. 7 c, d)). It occurs frequently in association with melanterite and or gypsum. In fact, Rozenite+Melanterite is one of the most well represented assemblages, developing botryoidal or reticulated aggregation (Fig. 7 e)).

Fig. 7. Field images of representative sulphate efflorescences.

a) Fragile white rosettes of gypsum; b) Gypsum rosettes cemented by jarosite; c) Rozenite in plaques on desiccation fractures network; d) Powdered efflorescences of Rozenite+Gypsum+Sulphur; e) General aspect of the efflorescences including rozenite and melanterite with minor oxyhydroxides; f) Detail of melanterite (green globules) and of its weathering products rozenite (white) and oxyhydroxides (brown); g) Microenvironment of salt precipitation controlled by humidity conditions comprising rozenite + melanterite $+\mathrm{Al}$-sulphates.

Individually, rozenite appears as white rosette or as whitish silky powder, while melanterite forms green or blue-green globules (Fig. 7 f)) with humid-touch. Encrustations, characterized by 
roughness, were observed during prolonged dry periods. The variety of colour shades, observed in the field images, is due to the impurity of the aggregates and it is consistent with the mineralogical evolution of these salts. It is known from literature that melanterite weathers by dehydration and oxidation to form rozenite (white) and oxyhydroxides (yellow-ochre) (Nordstrom and Alpers, 1999; Chou et al., 2002; Jerz and Rimstidt, 2003). Such assemblages as well as the relationship with aluminium sulphates were confirmed by observations around the small channel illustrated in Fig. 7 g)). It represents a microenvironment controlled by topographic irregularity and by the emergence of acidic effluent. The slow flow of AMD allows the sequential precipitation of several soluble minerals. Melanterite and Al-sulphates (such as alunogen and khademite) prefer the interior sheltered portion of the channel, with higher humidity, whereas rozenite was identified at the most sunlight exposed and consequently driest areas.

Al-sulphates were rarely found without melanterite, forming intergrowths that make nearly impossible to isolate single phases. This is confirmed by SEM study (Fig. 8). In these assemblages, foliated crystals of Al-sulphates form radiated aggregates that grow over melanterite, which by its turn presents well developed prismatic crystals. Halotrichite was found with typical acicular habit and can be seen as an exception because it forms pure concretions. This mineral is more abundant at the skarn pits resulted from open pit mining, where it grows as white masses, in coexistence with amorphous spherical iron-sulphate.

Fig. 8. Morphology of typical intergrowth between melanterite and Al-sulphates (probably alunogen e khademite). SEM (SE) images and respective EDS spectra for representative samples.

Although rare, siderotil was detected in assemblages carrying melanterite and aluminium sulphates (Fig. 6). When compared with the more common Rozenite+Melanterite assemblage, the Melanterite+Siderotil showed a much intense blue colour, which may be reflecting the 
incorporation of cooper by melanterite, like it was demonstrated by Jambor and Traill (1963). At Valdarcas it wasn't detected the coexistence of the three minerals melanterite, siderotil and rozenite, which is consistent with the results of the cited authors that demonstrated the preferential evolution of cooper-bearing melanterite by dehydration to siderotil, in spite of rozenite under the same conditions.

The assemblage Rozenite+Gypsum+Sulphur was found to form well-crystallized aggregates. They occur as very fine grained yellow-coloured powders, often fairly thick $(1-2 \mathrm{~cm})$, characterized by softness and by intense sulphur odour. SEM study has revealed that native sulphur occurs with euhedral crystals dispersed over the sulphate efflorescences.

\subsubsection{Distribution, seasonal behaviour and paragenesis}

Soluble sulphates were abundantly observed at the waste-dumps and rarely along the Poço Negro creek. Here, gypsum and rozenite were the only identified soluble salts. They occur at the margins of the creek, episodically, during evaporative periods. Fig. 9 shows the distribution of the sulphate-mineral assemblages over the waste-dumps surface, for winter and summer conditions.

Fig. 9. Cartographic distribution of the most typical sulphate-minerals in extreme seasonal conditions. a) summer; b) winter.

During summer, efflorescent blooms of gypsum and rozenite were observed as thick accumulations that cover great extensions of the exposed surfaces. Occasionally, during the most prolonged dry periods, native sulphur joints to this assemblage. The way the welldeveloped sulphur crystals appear over sulphates suggests that sulphur belongs to a latest stage 
of slow deposition relative to sulphate minerals. Melanterite and Al-sulphates were only observed in narrow sheltered areas, in the presence of remnant effluent.

In winter, gypsum rosettes grow even on the most exposed vertical slopes of the wastedumps in accordance with the relative low solubility of this sulphate. Highest mineralogical diversity was observed during fairly long-lasting evaporation periods (one or two weeks) that succeed intensive rainfall periods (often in February). In these conditions, melanterite was the first Fe-sulphate to be identified, followed by the Al-sulphates. If evaporation conditions were persistent, it was possible to observe the assemblage Rozenite+Melanterite (major rozenite), at the most sunny exposed conditions. These field observations, combined with the morphologic features, indicate that Al-sulphates precipitate after melanterite. Fig. 8 shows Al-sulphates over melanterite crystals, suggesting that the latest deposition of aluminium may be the result of iron depletion in the solution.

Interpretation of the occurrences and distribution justify summarizing the following remarks:

- There are microenvironments for mineral precipitation, related with topographic irregularities that have allowed a variety of exposure conditions to the climate elements; for instance, erosion has created cavernous shelters, even at the most vertical and climate exposed slopes, that ensure the persistence of the most soluble salts (melanterite and Al-sulphates) during winter (protecting them from dissolution) and during summer (protecting them from desiccation).

- Melanterite occurs preferably near the most acidic seepages, indicating the proximity to its paragenetic precursors (mainly pyrrhotite); table 3 shows the composition of the effluent at ValdR, which represents the most acidic AMD, from which this salt precipitates;

- At the most acidic seepages, melanterite precedes the Al-sulphates; this sequence suggests that the latest deposition of the aluminium minerals is controlled by high $\mathrm{Al}: \mathrm{Fe}$ ratios, resulting from iron depletion in the solution; this is in accordance with 
the paragenetic sequence observed by Jerz and Rimstidt (2003) in an abandoned mine located in Blue Ridge province in south-western Virginia;

- Eq. 4 and Eq. 5 describe two possible pathways for the precipitation of Al-sulphates from the chemical evolution of the sulphate and fluoro-complexes that may exist in solutions like AMD at ValdR (Table 3):

Alunogen: $2 \mathrm{AlSO}_{4}{ }^{+}{ }_{\text {(aq) }}+\mathrm{SO}_{4}{ }^{2-}{ }_{(\mathrm{aq})}+17 \mathrm{H}_{2} \mathrm{O}_{(\mathrm{l})} \leftrightarrow \mathrm{Al}_{2}\left(\mathrm{SO}_{4}\right)_{3} 17 \mathrm{H}_{2} \mathrm{O}_{(\mathrm{s})}$

Khademite: $\mathrm{AlF}^{2+}{ }_{(\mathrm{aq})}+\mathrm{SO}_{4}{ }_{(\mathrm{aq})}^{2-}+5 \mathrm{H}_{2} \mathrm{O}_{(\mathrm{l})} \leftrightarrow \mathrm{Al}\left(\mathrm{SO}_{4}\right) \mathrm{F}_{5} \mathrm{H}_{2} \mathrm{O}_{(\mathrm{s})}$

- Rozenite grows as efflorescent blooms, formed directly by evaporation of diluted AMD solutions, or than it results from melanterite dehydration at the most acidic seepages.

- The assemblage Rozenite+Gypsum+Sulphur is only stable at the summer driest conditions;

- Gypsum was observed in the entire range of temperature and humidity.

\subsubsection{AMD and pollution potential}

Table 3 presents the composition of the AMD at two selected sites, represented in Fig. 2. ValdR is located at the waste-dumps and coincides with the furthermost soluble salt diversity. V7 is located at the main effluent channel, approximately $500 \mathrm{~m}$ downstream from the base of the waste-dumps.

ValdR presents the lowest $\mathrm{pH}$ values and the higher levels of the generality of pollutants, except sodium and potassium. These properties are in accordance with the nature of the mineralwater interactions that prevails here. In fact, ValdR represents the result of slow water percolation in the interior of the waste-dumps. This allows the dissolution of silica and other chemical species, which are solubilised even from more stable minerals such as the silicates. Therefore, the contact with the parent sulphides explains the highly acidic effluent that is also 
very rich in sulphate and metals. The exceptions noted for sodium and potassium may be related with the strong precipitation of jarosite, which retains efficiently these elements.

Table 3 Composition of AMD at two different selected sites.

On the other hand, V7 represents more oxidized conditions and also the effect of dilution and other natural attenuation processes that occur as the creek flows away from the waste-dumps. This is well noted for metals and arsenic, given that levels are fairly lower at V7. In that condition, the chemical potential to precipitate metal soluble salts is quite lower, and, consequently, gypsum and rozenite are the only evanescent sulphates, rarely observed. Along the creek, the physical-chemical conditions impose the oxidation of iron and the precipitation of the iron(III)-bearing minerals presented in Table 2. Consequently, pollutants are being removed upstream by these minerals, as they retain iron, by incorporating it in their structure, and other metals and arsenic, by adsorption.

The ability of the identified soluble salts to produce acidic and metal-rich solutions was demonstrated through the experimental dissolution of selected typical samples. Fig. 10 shows the evolution of $\mathrm{pH}$ during the dissolution of halotrichite and of mixed Melanterite+Rozenite samples at the same conditions (concentration: $20 \mathrm{~g} / \mathrm{L} ; 20^{\circ} \mathrm{C}$ ).

Fig. 10. pH evolution during experimental dissolution of selected samples carrying Melanterite+Rozenite and Halotrichite, for a salt concentration of $20 \mathrm{~g} / \mathrm{L}$.

As it was observed by Frau (2000) during pure melanterite dissolution, a low and stable $\mathrm{pH}$ value was promptly established for both experienced samples. However, halotrichite shown higher acidic potential, with $\mathrm{pH}$ dropping from 5.7 to 3.2 in the first 2 minutes. These results are reflecting the reactions described by Eq. 6 to 9, which display the acid generation through the 
release of hydrogen ions from hydrous sulphates, like it was observed in several AMD environments (ex: Cravotta, 1994; Jambor et al., 2000).

$$
\begin{aligned}
& \mathrm{FeAl}_{2}\left(\mathrm{SO}_{4}\right)_{4} 22 \mathrm{H}_{2} \mathrm{O}_{(\mathrm{s})}+\mathrm{O}_{2(\mathrm{aq})} \leftrightarrow 4 \mathrm{Fe}(\mathrm{OH})_{3(\mathrm{~s})}+8 \mathrm{Al}(\mathrm{OH})_{3(\mathrm{~s})}+54 \mathrm{H}_{2} \mathrm{O}_{(\mathrm{l})}+16 \mathrm{SO}_{4}{ }_{(\mathrm{aq})}^{2-}+32 \mathrm{H}^{+}{ }_{\text {(aq })} \\
& \mathrm{FeSO}_{4} \mathrm{nH}_{2} \mathrm{O}_{(\mathrm{s})} \leftrightarrow \mathrm{Fe}^{2+}{ }_{\text {(aq) }}+\mathrm{SO}^{2-}{ }_{(\mathrm{aq})}+\mathrm{nH}_{2} \mathrm{O}_{(\mathrm{l})} \quad \text { ( } \mathrm{n}=4 \text { for rozenite; } \mathrm{n}=7 \text { for melanterite) } \\
& 4 \mathrm{Fe}^{2+}{ }_{(\mathrm{aq})}+4 \mathrm{H}^{+}{ }_{\text {(aq) }}+\mathrm{O}_{2(\mathrm{aq})} \rightarrow 4 \mathrm{Fe}^{3+}{ }_{(\mathrm{aq})}+2 \mathrm{H}_{2} \mathrm{O}_{(\mathrm{l})} \\
& \mathrm{Fe}^{3+}{ }_{(\mathrm{aq})}+3 \mathrm{H}_{2} \mathrm{O}_{(\mathrm{l})} \leftrightarrow \mathrm{Fe}(\mathrm{OH})_{3(\mathrm{~s})}+3 \mathrm{H}^{+}{ }_{(\mathrm{aq})}
\end{aligned}
$$

Hydrolysis of trivalent ions, such as aluminium from halotrichite, provides more significant acidity to the solution. In the case of Melanterite+Rozenite, oxidation of ferrous iron and subsequent hydrolysis and precipitation of ferric iron explain the observed $\mathrm{pH}$ fall. Fig. 11 presents the behaviour observed for the more common assemblage (Melanterite+Rozenite).

Fig. 11. Results of experimental dissolution of Melanterite+Rozenite. a) $\mathrm{pH}$ behaviour for different salt concentrations; b) Correlation between $\mathrm{pH}$ and salt concentration; c) Chemical composition of the remnant solution upon dissolution (for the tested concentration of $20 \mathrm{~g} / \mathrm{L}$ ).

The relation between salt concentration and the resultant solution $\mathrm{pH}$ was analysed for 15 minutes (Fig. 11 a)). The best fit between these parameters (Fig. 11 b)) is very close to the equation obtained by Frau (2000) with pure melanterite, which demonstrates the reproducibility of the process for salt efflorescences carrying both hydrated sulphates.

Chemical analysis of the resultant solution reveals that, as expected, upon dissolution, iron and sulphate are the dominant constituents (Fig. $11 \mathrm{c})$ ). However, other toxic elements are also released, providing indication that melanterite and rozenite are incorporating metals and arsenic via adsorption or coprecipitation.

These experiments demonstrate the role of the efflorescent mineralogy as transient storage of sulphate, acidity and metals. In that way, as the climatic seasonal cycles control the mineral 
stability, they have influence over the AMD properties and, therefore, they control its environmental impact.

In the event of rainfall, especially after prolonged dry periods, these highly soluble sulphates will dissolve and affect the properties of the receiving aquatic system. The environmental relevance of the rinse-out effect of efflorescent mineralogy in AMD systems is well documented (e.g. Nordstrom and Alpers, 1999). According to Frau (2000), the longer the dry period, the more intense the environmental impact during the subsequent wet period.

Fig. 10 and Fig. 11 show that iron and aluminium sulphates can be dissolved instantaneously, releasing pollutants into the water. Nevertheless, in field conditions, the relation between salts dissolution and aquatic contamination may be somewhat disguised by other factors such as dilution caused by rainfall. Consequently, a small rainy event may be of major concern, while that a strong and prolonged will assure dilution and therefore minimize the environmental risk.

\subsection{Iron-rich ochre precipitates}

Ochre precipitates of iron (III)-bearing minerals can be found at the waste-dumps and along the effluent channel. Fig. 12 exemplifies representative occurrences as:

- flocculated materials on the water-air interface (Fig. $12 \mathrm{a}, \mathrm{b}$ )),

- streambed coatings, that progress to encrusting as precipitation proceeds (Fig. 12 c)),

- iron-cements inside solid crusts (Fig. $12 \mathrm{~d}$, e)).

Encrusting develops as secondary minerals are accumulated, in such a way that the most indurate crusts represent an advanced stage of ochre precipitation. They occur typically at the waste-dumps, and, convert over time to iron-rich hardpans, herein defined accordingly with Lottermoser and Ashley (2006). In such hardpans, the iron (III)-bearing minerals are the typical cements, acting as strong binding agents for mine wastes. Others, less solid or even loosely, 
modes of occurrence, are broadly distributed since they can be observed in the entire system, including at the confluence in the Coura River.

Fig. 12. Field images of representative occurrences of ochre precipitates. a) water-floating brittle films displaying iridescence; b) Thick layers of orange sludge in the water-air interface; c) Encrusted coatings on the surfaces of the effluent channels; d, e) ochre-cements inside ironrich hardpans.

\subsubsection{Mineralogy and morphology}

Jarosite, schwertmannite and goethite are the main components of generally impure ochre precipitates. Ferrihydrite and lepidocrocite are rare and have restricted occurrences. The first was only observed in incipient and very fragile crusts that were collected after long lasting rainy periods. The second was identified inside very solid masses, in association with other supergene materials like sulphur and goethite, composing the cement of the most iron-rich hardpans.

From the more common minerals, the hydroxysulphate jarosite is the most crystalline. It is often identified as pure coatings at the most acidic seepages, where it gives a yellow colour to the exposed surfaces. It also forms mixtures with other minerals, principally schwertmannite, encrusting the effluent channels. Schwertmannite occurs mainly as brittle iridescent thin films and as light orange sludge. Both types of occurrences are fragile and consequently easily broken and dispersed in the water flow. During summer, in small remnant seeps and in slow flowing water, it is possible to observe several millimetres layers of bright orange sludge composed by pure schwertmannite. In those conditions its identification is rather simple because, although poorly crystalline, it has an unconfoundable diffraction pattern. Morphological features, observed in SEM-SE (Fig. 13), are diagnostic, especially valuable when schwertmannite occurs in complex mixtures. Fig. 13 c) shows tubular aggregates with typical specular and foam habits. 
These morphological aspects suggest that crystal growth take place as foam structures from thin and continuous iron rich films .

Fig. 13. SEM-SE images showing morfological characteristics of the iron(III)-minerals that compose the ochre precipitates. a) sample with jarosite (JT) and schwertmannite (Sch) colected at V4; b) sample composed of poorly crystalline goethite collected at V7; c) typical habits of schwermannite and EDS spectrum of spherical schwertmannite.

Goethite is generally poorly to moderately crystalline and presents spherical habit (Fig. 13b)). The most powdered aggregates are often enriched with sulphate. It occurs at the wastedumps, but it is more abundant along the creek, where it forms light orange mixtures with schwertmannite. Pure goethite is more common at higher distances from waste-dumps, where it appears as orange to brown precipitates coating the rock surfaces.

The evidence of crystallinity, expressed by difractometer analysis, decreases in the following order: Jarosite-Goethite-Schwertmannite.

\subsubsection{Environmental relevance of ochre-precipitates distribution}

The distribution of the ochre precipitates, encrusting streambeds (Fig. 14), deserves the following comments:

- at the waste-dumps (ValdR, V1, V2 and V6) prevails jarosite; its content decreases along the creek as the distance relative to the waste-dumps increases, until it disappears at V7.

- At V7 occur the goethite-richer precipitates. 
- Along the creek, between V3 and V9, the mixtures are composed by variable proportions of schwertmannite and goethite with minor jarosite;

- As distance to the waste-dumps increase there is a progressive importance of goethite relatively to schwertmannite.

- In the longest rainy periods the precipitates formed at the waste-dumps appear enriched in low crystallinity materials.

The distribution reported in Fig. 14 agrees with the paragenetic relations described by Bigham et al. (1996) for jarosite, schwertmannite and goethite. It is known that jarosite forms under more acidic conditions then the others (Baron and Palmer, 1996; Swayze at al., 2000), which explains its predominance at ValdR. Here, persistence of jarosite is insured by the constant supply of acidic effluent from the interior of the waste-dumps and also resulting from the dissolution of the soluble sulphates that were abundantly observed at this site.

Downstream, between V3 and V9, the effect of dilution induces an increase in the $\mathrm{pH}$ values, which promotes the instability of jarosite relatively to the oxyhydroxides. Eq. (10) give the transformation reaction, which produce protons. Nevertheless, dilution remains the prevailing factor, inducing $\mathrm{pH}$ to rise

$\mathrm{KFe}_{3}\left(\mathrm{SO}_{4}\right)_{2}(\mathrm{OH})_{6(\mathrm{~s})}+3 \mathrm{H}_{2} \mathrm{O}_{(\mathrm{l})} \leftrightarrow 3 \mathrm{Fe}(\mathrm{OH})_{3(\mathrm{~s})}+\mathrm{K}_{(\mathrm{aq})}^{+}+2 \mathrm{SO}_{4}{ }_{(\mathrm{aq})}+3 \mathrm{H}^{+}{ }_{(\mathrm{aq})}$

In those less acidic conditions, jarosite can be replaced by schwertmannite. The same occurs at the waste-dumps (V1, V2 and V6) during the rainiest periods, which suggests the influence of seasonal variations in the minerals distribution.

At the upper section of the Poço Negro creek, the low crystallinity and the schwertmanniterich compositions may be revealing an incipient stage in the paragenetic sequence. On the other hand, goethite represents a more advanced stage, since it forms at higher $\mathrm{pH}$ values and as a transformation product of less crystalline phases. In fact, it is known that over time 
schwertmannite may convert to goethite (Bigham et al., 1996; Bigham and Nordstrom, 2000). This will explain the downstream enrichment in goethite and its predominance at the more distant sampling site (V7).

Fig. 14. XRD analysis and description of representative samples from the encrusted streambeds. JT - Jarosite; GO - Goethite; Sch - Schwertmannite; Qz - Quartz; PI - Pyrite. The $\mathrm{pH}$ range was extracted from Valente (2004) and Valente and Leal Gomes (2008).

These results indicate that XRD data on the ochre mixtures may give valuable information regarding the environmental conditions related with AMD. In that way, abundance of jarosite outside the waste-dumps may indicate a recent event of acidic contamination, which is, in general, due to erosion processes taken place at the waste-dumps. This was observed after episodic instability, promoted by strong rainfall events or by anthropogenic activities, such as the illegal practice of sports on the waste-dumps. In those conditions, the spreading of the jarosite halo is a response to higher contents of acidity and sulphate in the effluent, which is promoted by the chemical reactivation of sulphide-rich wastes. Progressively, dilution attenuates this effect and schwertmannite gains importance in the ochre mixtures. In fact, the presence of low crystallinity materials, such as the floating films of schwertmannite, marks the incipient effect of natural attenuation processes. Long lasting stability periods promote further evolution to goethite. As a result of the repetition of these processes, the channel is coated with encrusted layers that present alternated colour and composition.

\section{Conclusion}

The environmental minerals associated with AMD at Valdarcas occur as salt efflorescences or as ochre mixtures, both typically iron-dominant. The abundance, rather than the variety, of 
iron minerals is a consequence of the primordial composition of the mine wastes, since pyrrhotite and pyrite are the most abundant parent sulphides, leading to the generation of highly iron-rich solutions.

Regarding efflorescences, the majority are composed by gypsum and by the simple hydrated ferrous sulphates, rozenite and melanterite. Lesser amounts of Al-sulphates were also frequently detected. Salts of other transition metals were more rarely observed, which reflects the chemical potential of the iron-rich AMD from which they precipitate. The principal modes of occurrence, the composition of the mineral assemblages, as well as the geometry of the intergrowths, suggest that the distribution and paragenesis of soluble salts are controlled by the following main factors:

- climatic seasonal variation - determines the evaporation conditions and the water availability; consequently controls the succession of precipitation-dissolution cycles and the transformations allied to hydration and neutralization.

- topography and erosion - diversify the microclimate conditions that behave as thermodynamic microenvironments for precipitation at the waste-dumps.

- composition of AMD, mainly acidity and the activity of sulphate and metals - variations in composition, especially concerning the relation between iron and other metals, control the element fractionation, by diversifying the equilibrium conditions.

- hydrologic configuration of the superficial drainage - controls the fluxes of percolation, as well as the existence of seepages and ponded water, that by its turn influences the chemical composition and the oxidation conditions of AMD.

Laboratory experiments with efflorescences carrying iron and aluminium sulphates have demonstrated the ability to produce acidic, metal and sulphate rich solutions. In that way, these experiments close simulate the influence that these type of environmental minerals exercise over the quality of the nearby aquatic system. Such influence is especially important during rainfall events, after dry periods, since dissolution may promote peaks of acidic contamination, related with AMD emanating from the waste-dumps. 
Ochre precipitates were the other relevant environmental minerals identified at Valdarcas. They refer to iron (III)-bearing minerals that include jarosite, schwertmannite and goethite and more rarely ferrihydrite and lepidocrocite. These minerals occur with variable proportions in the ochre mixtures that are disseminated in the waste-dumps and downstream, in the riverine system. The relative mineral proportions, in concert with the crystallinity of the mixtures, is rather variable downstream and over time, accordingly with the AMD conditions. For instance, the detection of well crystalline precipitates, enriched in jarosite, at lower sections of the creek, indicates the occurrence of recent contaminant events, generally related with erosion processes at the waste-dumps.

During the year of 2007, engineering rehabilitation works were conducted at the wastedumps, in order to homogenize de surface and to implement measures for erosion control. In the beginning of 2008 the waste-dumps, which have been covered with soil, were also seeded and planted with autochthon vegetation. Future impact of this rehabilitation project should be, from now on, subject to monitoring. For that purpose, mineralogical composition and spatial distribution of ochre precipitates along the Poço Negro creek can be proposed as expeditious mineralogical indicators, which enhance the relevance of these AMD-precipitates as environmental minerals.

\section{Acknowledgements}

The authors thank to colleague Fernanda Lima for her help with field work. They are grateful to Lucia Guise and A. Azevedo for assistance with chemical analysis and XRD analysis. They are also indebted to the two anonymous reviewers whose wise remarks allowed to improve the manuscript. 


\section{References}

Alpers, C.N.; Blowes, D.W.; Nordstrom, D.K.; Jambor, J.L. Secondary minerals and acid minewater chemistry. In: Jambor, J.L.; Blowes, D.W. eds. Short course handbook on environmental geochemistry of sulfide mine-wastes. Mineral Assoc Can, 1994: 247-270.

Alpers, C.N.; Jambor, J.L.; Nordstrom, D.K. (eds) Sulfate minerals: Crystallography, geochemistry and environmental significance. Rev Mineral Geochem 2000; 40.

Baron, D.; Palmer, C.D. Solubility of jarosite at $4-35^{\circ}$ C. Geochim et Cosmochim Acta 1996; 60: 185-195.

Bhatti, T.M.; Bigham, J.M.; Carlson, L.; Tuovinen, O.H. Mineral products of pyrrhotite oxidation by Thiobacillus ferrooxidans. Appl Environ Microbiol 1993; 59: 1984-1990.

Bigham, J.M.; Carlson, L.; Murad, E. Schwertmannite, a new iron oxyhydroxy-sulphate from Pyhasalmi, Finland, and other localities. Mineral Mag 1994; 58: 641-648.

Bigham, J.M.; Schwertmann, U.; Traina, S.J.; Winland, R.L.; Wolf, M. Schwertmannite and the chemical modeling of iron in acid sulfate waters. Geochim et Cosmochim Acta 1996; 60: 2111-2121.

Bigham, J.M.; Nordstrom, D.K. Iron and aluminum hydroxysulfates from acid sulfate waters In: Alpers, C.N.; Jambor, J.L.; Nordstrom, D.K. eds. Sulfate minerals: Crystallography, geochemistry and environmental significance. Rev Mineral Geochem 2000; 40: 351-403.

Buckby, T.; Black, S.; Coleman, M.L.; Hodson, M.E. Fe-sulphate-rich evaporative mineral precipitates from the Rio Tinto, southwest Spain. Mineral Mag 2003; 67: 263-278.

Carlson, L.; Bigham, J.M.; Schwertmann, U.; Kyek, A.; Wagner, F. Scavenging of As from acid mine drainage by schwertmannite and ferrihydrite: a comparison with synthetic analogues. Environ Sci Technol 2002; 36: 1712-1719. 
Chou, M.; Seal, R.R.; Hemingway, B.S. Determinantion of rozenite-melanterire and chalcanthite-bonattite equilibria by humidity measurements at $0.1 \mathrm{MPa}$. Am Mineral 2002; 87: 108-115.

Cotter-Howells, J.D.; Campbell, L.S.; Valsami-Jones, E.; Batchelder, M. (eds) Environmental mineralogy: microbial interactions, anthropogenic influences, contaminated land and waste management. The Mineralogical Society series, 2000; 9.

Courtin-Nomade, A.; Bril, H.; Neel, C.; Lenain, J. Arsenic in iron cements developed within tailings of a former metalliferous mine - Enguialès, Aveyron, France. Appl Geochem 2003; 18: 395-408.

Cravotta III, C.A. Secondary iron-sulfate minerals as sources of sulfate and acidity: Geochemical evaluation of acidic groundwater at a reclaimed surface coal mine in Pennsylvania. In: Alpers, C.N.; Blowes, D.W. eds. Environmental geochemistry of sulfide oxidation, Am Chem Soc Symp Ser, 1994; 550: 345-364.

Dold, B. Dissolution kinetics of Schwertmannite and Ferrihydrite in oxidized mine samples and their detection by differential X-ray diffraction (DXRD). Appl Geochem 2003; 18: 15311540 .

Dold, B.; Fontboté, L. Element cycling and secondary mineralogy in porphyry copper tailings as a function of climate, primary mineralogy and mineral processing. J Geochem Explor 2001; 74: 3-55.

Elbaz-Poulichet, F.; Braungardt, C.; Achterberg, E.; Morley, N.; Cossa, D.; Beckers, J.; Nomérange, P.; Cruzado, A.; Leblanc, M. Biogeochemistry in the Tinto-Odiel rivers (Southern Spain) and in the Gulf of Cadiz: a synthesis of the results of TOROS project. Cont Shelf Res 2001; 21: 1961-1973.

Evangelou, V.P.; Zhang, Y.L. A review: Pyrite oxidation mechanisms and acid mine drainage prevention. Crit Rev Env Sci Tec 1995; 25: 141-199. 
Frau, F. The formation-dissolution-precipitation cycle of melanterite at the abandoned pyrite mine of Genna Luas in Sardinia, Italy: environmental implications. Mineral Mag 2000; 64: 995-1006.

Gilbert, S.E.; Cooke, D.R.; Hollings, P. The effects of hardpan layers on the water chemistry from the leaching of pyrrhotite-rich tailings material. Environ Geol 2003; 44: 687-697.

Gomes, E.P.; Favas, P. Mineralogical controls on mine drainage of the abandoned Ervedosa tin mine in north-eastern Portugal. Appl Geochem 2006; 21:1322-1334.

Gray, N.F. Acid mine drainage composition and the implications for its impact on lotic systems. Water Res 1998; 32: 2122-2134.

Hammarstrom, J.M.; Seal II, R.R.; Meier, A.L.; Jackson, J.C. Weathering of sulfidic shale and copper mine waste: secondary minerals and metal cycling in Great Smoky Mountains National Park, Tennessee, and North Carolina, USA. Environ Geol 2003; 45: 35-57.

Hammarstrom, J.M.; Seal II, R.R.; Meier, A.L.; Kornfeld, J.M. Secondary sulphate minerals associated with acid drainage in the eastern US: recycling of metals and acidity in surficial environments. Chem Geol 2005; 215: 407-431.

Harris, D.L.; Lottermoser, B.G.; Duchesne, J. Ephemeral acid mine drainage at the Montalbion silver mine, North Queensland. Aust J Earth Sci 2003; 50: 797-809.

Hochella, M.F. Jr. Sustaining earth: Thoughts on the present and future roles of mineralogy in environmental science. Mineral Mag 2002; 66: 627-652.

Hudson-Edwards, K.A.; Schell C.; Macklin, M.G. Mineralogy and geochemistry of alluvium contaminated by metal mining in the Rio Tinto area, southwest Spain. Appl Geochem 1999; 14: $1015-1030$.

Jambor, J.L.; Traill, R.J. On rozenite and siderotil. Can Mineral 1963; 7: 751-763.

Jambor, J.L.; Boyle, R.W. Gunningite, a new zinc-sulfate from the Keno Hill - Galena Hill area, Yukon. Can Mineral 1962; 7: 209-218. 
Jambor, J.L.; Blowes, D.W. Theory and applications of mineralogy in environmental studies of sulphide bearing mine wastes. In Cabri, L.J.; Vaughan, D.J. eds. Modern approaches to ore and environmental mineralogy. Mineral Assoc Can Short Course, 1998; 27: 367-401.

Jambor, J.L.; Nordstrom, D.K.; Alpers, C.N. Metal-sulfate salts from sulfide mineral oxidation. In: Alpers, C.N.; Jambor, J.L.; Nordstrom, D.K. eds. Sulfate minerals: Crystallography, geochemistry and environmental significance. Rev Mineral Geochem 2000; 40: 305-350.

Jerz, J.K.; Rimstidt, J.D. Efflorescent iron sulphate minerals: Paragenesis, relative stability, and environmental impact. Am Mineral 2003; 88: 1919-1932.

Kawano, M.; Tomita, K. Geochemical modeling of bacterially induced mineralization of schwertmannite and jarosite in sulfuric acid spring water. Am Mineral 2001; 86: 1156-1165.

Keith, C.N.; Vaughan, D.J. Mechanisms and rates of sulphide oxidation in relation to the problems of acid rock (mine) drainage. In: Campbell, L.S.; Valsami-Jones, E.; Batchelder, M. eds. Environmental Mineralogy: microbial interactions, anthropogenic influences, contaminated land and waste. The Mineralogical Society Series, 2000; 9: 117-139.

Kwong, Y.T.; Lawrence, J.R. Mineralogical controls of sulfide oxidation. National Hydrology Research Institute, NHRI contribution nº 94010; 1994.

Lottermoser, B. Mine wastes - characterization, treatment and environmental impacts. Springer, Berlin, 2003.

Lottermoser, B.; Ashley, P. Mobility and retention of trace elements in hardpan-cemented cassiterite tailings, north Queensland, Australia. Environ Geol 2006; 50: 835-846.

McKibben, A.A.; Barnes, H.L. Oxidation of pyrite in low temperature acidic solutions: rate laws and surface textures. Geochim et Cosmochim Acta 1986; 50: 1509-1520.

Murad, E., Rojík, P. Iron-rich precipitates in a mine drainage environment: Influence of $\mathrm{pH}$ on mineralogy. Am Mineral 2003; 88: 1915-1918. 
Nordstrom, D.K.; Southam, G. Geomicrobiology of sulfide mineral oxidation. In: Banfield, J.F.; Nealson, K.H. eds. Geomicrobiology: interactions between microbes and minerals. Rev Mineral 1997; 35: 361-390.

Nordstrom, D.K.; Alpers, C.N. Negative pH, efflorescent mineralogy, and consequences for environmental restoration at the Iron Mountain Superfund site, California. Proc. Nat. Acad. Sci. US 1999; 96: 3455-3462.

Pérez-López, R.; Nieto, J.M.; Alvarez-Valero, A.M.; Almodôvar, G.R. Mineralogy of the hardpan formation processes in the interface between sulfide-rich sludge and fly ash: Applications for acid mine drainage mitigation. Am Mineral 2007; 92:1966-1977.

Plumlee, G.S.; Nash, J.T. Geoenvironmental models of mineral deposits - fundamentals and applications. In: Edward du Bray ed. Preliminary compilation of descriptive geoenvironmental mineral deposits USGS, Open-File Report 1995; 95-831.

Ritchie, A.I.M. Rates of mechanisms that govern pollution generation from pyretic wastes. In: Alpers, C.N.; Blowes, D.W. eds. Environmental geochemistry of sulfide oxidation, Am Chem Soc Symp Ser, 1994; 550: 108-122.

Sainz, A.; Grande, J.A.; de la Torre, M.L. Characterization of heavy metal discharge into the Ria of Helva. Environ Int 2004; 30: 557-566.

Sanchéz, J.; Pamo, E.L.; Santofimia, E.; Aduvire, O.; Reyes, J.; Barettino, G. Acid mine drainage in the Iberian Pyrite Belt (Odiel river watershed, Huelva, SW Spain): Geochemistry, mineralogy and environmental implications. Appl Geochem 2005; 20: 13201356.

Swayze, G.; Smith, K.S.; Clark, R.N.; Sutley, S.J.; Pearson, R.M.; Vance, J.S.; Hageman, P.L.; Briggs, P.H.; Meier, A.L.; Singleton, M.J.; Roth, S. Using imaging spectroscopy to map acidic mine waste. Environ Sci Technol 2000; 34: 47-54.

Schwertmann, U.; Carlson, L.; Murad, E. Properties of iron oxides in two Finnish lakes in relation to the environment of their formation. Clay Clay Miner 1987; 35: 297-304. 
Singh, B.; Wilson, M.J.; McHardy, W.J.; Fraser, A.R.; Merrington, G. Mineralogy and chemistry of ochre sediments from an acid mine drainage near a disused mine in Cornwall, UK. Clay Miner 1999; 34: 301-317.

Smith, K.S.; Ranville, J.F.; Plumlee, G.S.; Macalady, D.L. Predictive double-layer modeling of sorption in mine drainage systems. In: Jenne, E.A. ed. Adsorption of metal by geomedia Variables, mechanisms and model applications, Academic Press, 1998: 522-548.

Valente, T. Modelos de caracterização do impacte ambiental para escombreiras reactivas equilíbrio e evolução de resíduos de actividade extractiva. PhD. thesis, Universidade do Minho, Portugal [in Portuguese, with English abstract]; 2004.

Valente, T.; Leal Gomes, C. Caracterização dos produtos ocres de drenagem da escombreira de Valdarcas - indicadores das condições de drenagem ácida. XIV Semana de Geoquímica, Aveiro, Portugal, 2005: 535-540.

Valente, T.; Leal Gomes, C. The role of two acidophilic algae as ecological indicators of acid mine drainage sites. J Iber Geol 2007; 33: 283-294.

Valente, T.; Leal Gomes, C. Fuzzy modelling of acid mine drainage environments using geochemical, ecological and mineralogical indicators. Environ Geol (2008); DOI 10.1007/s00254-008-1344-7.

Valsami-Jones, E. Section 3: Minerals in contaminated environments. In: Campbell, L.S.; Valsami-Jones, E.; Batchelder, M. eds. Environmental Mineralogy: microbial interactions, anthropogenic influences, contaminated land and waste. The Mineralogical Society Series 2000; 9: 201-205.

Vaughan, D.J.; Pattrick, R.D.; Wogelius, R.A. Minerals, metals and molecules: ore and environmental mineralogy in the new millennium. Mineral Mag 2002; 66: 653-676.

\section{Figure legends}


Fig.1. Location of Valdarcas mining site in Northern Portugal and surface map of the waste-dumps.

Fig. 2. Location of the sampling stations, for ochre precipitates and AMD, at the wastedumps and along the main effluent channel (Poço Negro creek).

Fig. 3. Iterative protocol for mineral identifications in soluble sulphate assemblages. XRD

- Powder x-ray diffraction; SEM - Scanning electron microscopy; SE - Secondary electrons.

Fig. 4. XRD pattern from a complex assemblage including the abundant iron sulphates (rozenite and melanterite) and the more rare zinc (gunningite) and alkaline earth metals (starkeyite and gypsum) sulphates. Pattern peaks from ICDD.

Fig. 5. XRD patterns of efflorescences carrying several Al-sulphates. Pattern peaks from ICDD. Powder x-ray diffraction; SEM - Scanning electron microscopy; SE - Secondary electrons.

Fig. 6. XRD pattern from a complex assemblage including iron (melanterite and siderotil), manganese (mallardite) and aluminium sulphates (tamarugite). Pattern peaks from ICDD.

Fig. 7. Field images of representative sulphate efflorescences. a) Fragile white rosettes of gypsum; b) Gypsum rosettes cemented by jarosite; c) Rozenite in plaques on desiccation fractures network; d) Powdered efflorescences of Rozenite+Gypsum+Sulphur; e) General aspect of the efflorescences including rozenite and melanterite with minor oxyhydroxides; f) Detail of melanterite (green globules) and of its weathering products rozenite (white) and oxyhydroxides (brown); g) Microenvironment of salt precipitation controlled by humidity conditions comprising rozenite + melanterite $+\mathrm{Al}$-sulphates .

Fig. 8. Morphology of typical intergrowth between melanterite and Al-sulphates (probably alunogen e khademite). SEM (SE) images and respective EDS spectra for representative samples.

Fig. 9. Cartographic distribution of the most typical sulphate-minerals in extreme seasonal conditions. a) summer; b) winter. 
Fig. 10. pH evolution during experimental dissolution of selected samples carrying Melanterite+Rozenite and Halotrichite, for a salt concentration of $20 \mathrm{~g} / \mathrm{L}$.

Fig. 11. Results of experimental dissolution of Melanterite+Rozenite. a) $\mathrm{pH}$ behaviour for different salt concentrations; b) Correlation between $\mathrm{pH}$ and salt concentration; c) Chemical composition of the remnant solution upon dissolution (for the tested concentration of $20 \mathrm{~g} / \mathrm{L}$ ).

Fig. 12. Field images of representative occurrences of ochre precipitates. a) water-floating brittle films displaying iridescence; b) Thick layers of orange sludge in the water-air interface; c) Encrusted coatings on the surfaces of the effluent channels; d, e) ochre-cements inside ironrich hardpans.

Fig. 13. SEM-SE images showing morfological characteristics of the iron(III)-minerals that compose the ochre precipitates. a) sample with jarosite and schwertmannite colected at V4; b) sample composed of poorly crystalline goethite collected at V7; c) typical habits of schwermannite and EDS spectrum of spherical schwertmannite.

Fig. 14. XRD patterns and description of the ochre precipitates from the encrusted effluent channels. JT - Jarosite; GO - Goethite; Sch - Schwertmannite; Qz - Quartz; PI Pyrite. The $\mathrm{pH}$ range at each sampling site was extracted from Valente (2004) and Valente and Leal Gomes (2008). 


\section{Table legends}

Table 1 Most typical minerals from the ore deposit that were also identified at the waste-dumps (Valente, 2004).

Table 2 AMD-precipitates identified at Valdarcas.

Table 3 Composition of AMD at two different selected sites. 